\title{
The First Three Years of Presidential System of Government in the Light of Basic Principles, Practices and Revision Requests
}

(Research Article)

Temel İlkeler, Uygulama ve Revizyon Talepleri Işı̆̆ında Cumhurbaşkanlı̆̆

Hükümet Sisteminin İlk $\ddot{U}_{c}$ Yllı

Doi: 10.29023/alanyaakademik. 883477

\author{
Ahmet KIZILKAYA \\ Dr., Turkish Ministry of National Education, Ankara/Turkey \\ ahmetkizilkaya111@gmail.com \\ Orcid ID: 0000-0002-7275-3664
}

How to cite this article: Klzllkaya, A. (2021). "The First Three Years of Presidential System of Government in the Light of Basic Principles, Practices and Revision Requests. "Alanya Academic Review, 5(2), pp.693-704.

Keywords:

Presidential System of

Government,

parliamentarism,

presidential system,

system revision,

Turkey

Received: 20.02 .2021

Accepted: 26.04 .2021

\begin{abstract}
Turkey adopted a new management model which is also called the Presidential System of Government by referendum held on April 16, 2017. This model has come into force after the elections held on June 24, 2018, and Recep Tayyip Erdoğan became the first president of the Presidential Government System. Eventually, Turkey has moved away from the parliamentary system which is shaped in the developmental stages of TurkishOttoman modernization and has approximately 150-years history and adopted a new management model of presidential system which can be considered as a Turkey-specific version. In the scope of this study, the basic principles and implementation practices of the Presidential System of Government, which is about to complete its third year, and the revision requests emerged in the process are discussed. The aim of this study is to reveal the uniqueness of Turkey's new management model, and to show what the equivalence of the system corresponds to in the constitutional law literature context.
\end{abstract}

\section{INTRODUCTION}

The government system debates, which includes the quest for the principles and rules to be the basis of and model to be taken for defining how the relations among the legislative, executive and judicial powers that constitute the basic elements of modern state formation to be shaped, have a history spreading over the entire republican period. These debates toward the discovery of a more rational, more efficient, and faster management mechanism that will best represent of Turkey's political, social and cultural reality have occurred in a course that become different according to the specific conditions, priorities and needs of each period, and have come until today. 
Within this ongoing quest since March 19, 1877, when Turkey became acquainted with the concept of parliament, Parliamentary Government System, which was adopted with the 1921 Constitution and based on the unity of powers, has been moved into. This system had been changed with the 1924 Constitution, which was adopted after the Declaration of the Republic and a parliamentary system based upon soft separation of powers has been adopted. After all, between 1923 and 1946 when the one-party regime prevailed, a hybrid model that can be considered as a mixture of both systems was taken as basis. This hybrid model, whose dominant character is the parliamentary system, had also been continued both in the transition process to multi-party political life and the following Democrat Party period (1950-1960). Turkey experienced a transition to 'pure parliamentarism' with 1961 Constitution, and to 'rationalized parliamentarism' with 1982 Constitution so that these both constitutions are the product of a military coup period (Tekin 2015: 44-48; Y1ld1z 2015).

These political developments taking place in a political, legal and social order shaped by the military coups at short intervals resulted in a continuous management crisis due to the failure to formulate or apply the constitutional principles and rules that underpin the relations between the executive and legislative powers; and these developments have accelerated the debates about the change of the government system. The essence of these debates, which had started to intensify and gain continuity especially since the preparation process of the 1982 Constitution, was formed by the criticisms expressed against the double-headed executive system. Frequent incompatibilities among the double-headed executive powers consisting of empowered but irresponsible president, and prime minister and cabinet of ministers have led to system crises at times. Also, this has caused political and economic instability except for some extraordinary periods and has set the stage for military coups. This double headedness, arising from the construct of the parliamentary system operating under the pressure and control of the tutelage institutions (Karatepe et. al., 2017: 22), has been seen as the main obstacle to the establishment of a stable and strong management model by some academic and political community, and this has also constituted the main reason for the objections to the existing system and the quest for a new system.

Within the scope of these quests, presidency system suggestions have voiced as a result of the contention arising from the fact that the parliamentary democracy experience does not fit in Turkey's reality and meet Turkey's needs. In fact, the main factor that proposed this suggestion, expressed by various academic and political circles for all along time, for the agenda of politics and society and turned it into a serious debate on the government system is being defended the issue by the prime ministers and the presidents of the republic in the relevant period. The debates on the presidential system, which was placed at the center of the political agenda by Turgut Özal and Süleyman Demirel, who previously served both as prime minister and president, were getting so much into the idea and gained supporters during Recep Tayyip Erdogan's prime ministry period.

Erdogan's theses, who think that the clearance of a guardianship management system shaped by conventional military coups and/or coup attempts at frequent intervals, postmodern qualified intervention attempts to overthrow the civilian political powers that have come into power with the free will of the people, e-memorandum, closure cases to political parties, laws restricting / prohibiting individual rights and freedoms and similar applications can only be possible with the presidential system, has come to the fore as a strong challenge to the parliamentary system. 
Thus, in this period, an important amendment in the 1982 Constitution was made with the referendum held in 2007 as a beginning, and the regulation that made it possible for the president of the republic to be elected by the people was adopted. With this regulation, the government system in Turkey largely moved away from the parliamentary system and take the form of close to the semi-presidential system (Demirkaya 2018:14). The first election within the scope of the aforementioned regulation was held on 10 August 2014 and Recep Tayyip Erdoğan became the first president of Turkey Republic elected directly by the voters.

On the one hand, this development actually led to a rapid evolution of Turkey's government system towards the presidential regime, on the other hand it has made the double headedness in executive more visible. However, in a process where the parliamentary system and therefore the presence of the prime minister and the government continue formally, the direct election of the President by popular vote has put the system into a new crisis. As a result of the quests for overcoming this crisis and positioning the government system within a constitutional framework in line with the new status of the presidency, it was decided to hold a new referendum that anticipates amendments in the relevant articles of the 1982 Constitution. In the referendum held on April 16, 2017, approximately 51.5 percent of the people voted as "yes", and approved the arrangement presented as the "Presidential System of Government". As a result of the elections held on June 24, 2018, within the scope of this legal regulation, Erdogan was elected not only as the president once again, but as the sole empowered at the head of the executive. Thereby, the system crisis caused by the de facto situation has come to an end, and a new management model of presidential system, which can be considered as a Turkey-specific version, has been adopted to.

In this study, it is aimed to examine the basic principles, application practices and revision requests emerging during the process regarding the mentioned model, which is about to complete its third year. For this purpose, firstly, the prominent features and innovations of the new system were discussed, and then the implementation / implementation process was evaluated. After mentioning the debates about how the new system can be positioned in the constitutional law literature, the revision demands that emerged during the process were examined.

\section{BASIC QUALIFICATIONS OF THE SYSTEM AND ITS INNOVATIONS}

With the Presidential System of Government, the legislative, executive and judicial powers that constitute the three pillars of the state were revolutionized. In this new system positioning the President as the sole authoritative person in charge of the executive, a management model based on a relatively stiffer separation of powers compared to parliamentarism has been created. It is possible to say that this new model has three basic features from institutional perspective. The first of these features is the acceptance of the principle of the supremacy of the legislative, the second is the inclusion of regulations aimed at increasing the efficiency of the executive, and the third is the development of anti-lock mechanisms to make the system functional (Alkan 2018: 40). As for rationalization of these features in a more explanatory framework requires an understanding of how the relations between legislative and executive powers and these powers are formed in the new system.

In this context, the first point to be underlined is the fact that the Presidential System of Government did not make any difference in terms of consisting of the legislative power compared to the parliamentary system. In both systems, the legislative power consists of a 
unicameral structure. In the new model, however, it has been aimed to increase democratic participation and representation by making changes in the number of deputies and the election conditions. Accordingly, the number of deputies has been increased from 550 to 600 and the age of candidacy has been reduced from 25 to 18 . In addition, it has been aimed to hold the presidential and the general elections simultaneously by extending the electoral period from four to five years. Thus, the formation of a relatively stable political order was foreseen, in which the legislative and executive organs were elected via direct popular vote with two separate elections and the operation of both was not dependent on each other's approval. Moreover, as a requirement of the regulation, both the president and the parliament were given the authority to renew the elections. Due to the nature of the new system, vote of confidence and interpellation practices, which are characteristics of the classical parliamentary system and carried a meaning that the government bears legal liability towards the parliament, has also been abolished. Supervision of the presidential cabinet, which does not require the approval of the parliament and was established outside the parliament, was made possible through parliamentary inquiry, parliamentary investigation, general debate and written questions (Akçakaya et. al., 2018: 927; Turan 2018: 50).

In fact, this last issue, which is one of the innovations brought by the Presidential Government System towards the legislative field, is also an indicator of how the effectiveness of executive organ in the system has increased. Differ from the classical parliamentary system, a government structure has been formed, in which does not need to receive a vote of confidence from the parliament, cannot be fell off with interpellation, and can be established by the head of executive whose legitimacy of power vested directly from people. Alkan (2018: 41), explains the distinctive features of the government structure referring to the presidential decree, which is one of the most discussed concepts of the new system, as follows.

This system recognizes the authority of the president in the field of execution in order to ensure presidency accountability to the public and gives the policy-making initiative to the executive authority determined directly by election. Therefore, in order for the system to function the president should be furnished with the authority in terms of the issues in the field of execution including to determine the personnel of the presidency, to establish the necessary committees and to make the institutional revision which is the reflection of the service efficiency and the policy to be followed. This is the main reason why the president is empowered to issue decrees in presidential systems. The decree is an authority that ensures the president's accountability to the public and sets the stage for the public that can hold the president directly responsible, and it has been adopted in all presidential systems. Thus, in order to determine the legislative area in the Presidential system, it is necessary to look primarily at how the Presidential Decree is prepared in the new system.

The matters of the presidential decree mentioned by Alkan are elaborated in Article 104 of the Constitution, and the scope and bounds of the authority to issue decrees are clearly drawn. The article providing that the President of the Republic can issue decrees only on matters related to executive power excludes the fundamental rights, individual rights and duties, and political rights and duties from this area of jurisdiction. Moreover, constitutionally this authority is not allowed to be used for the subjects that are exclusively stipulated to be enact by law and clearly enacted. Furthermore, the comprehensiveness of Presidential decree has been limited by expressing that a decree published earlier will be abated in case of enactment by Grand National Assembly of Turkey (TBMM) on the same issue. According to Alkan (2018: 42), this article 
regulates the presidential decree, which left four areas to the regulatory power of the executive, while giving approximately eighty areas to the legislature.

However, it should be noted that although President decrees are limited to only four areas, the areas give a wide range of action to the executive because of their qualities and the fact that the acts in these areas are not subjected to legislative audit. The authority to issue decrees, which is valid in a wide range from the establishment and abolition of ministries to the foundation of public legal entities, is the result of the central role and position given to the executive power by the new system. As a matter of fact, the institutional structure of the new system has also been designed within the scope of this authority exclusively left to the executive power, and therefore to the president. The presidential organization forming the executive power was arranged with Presidential Decree No. 1 published in the Official Gazette, dated July 10, 2018. With the scope of the aforementioned regulation, new administrative units such as vicepresidency, offices and policy boards were established, and the number of ministries was reduced to 16 .

The innovations coming with the new system regarding the executive power are not limited to these issues. In this system, the president is allowed to maintain the ties with his political party even after the elections. With this opportunity, also referred to as the party-member presidency, the President has been enabled to preserve the influence and power over the party. Thus, the central position of the president in the system was expressed once again, and the efficiency of the executive power was desired to be strengthened.

Apart from these regulations, which determine the institutional architecture and qualities of the presidential system regarding the legislative and executive powers, some mechanisms have also been developed to prevent the deadlock in the system caused by a possible dispute between both powers. The first of these mechanisms, which can be examined under three separate titles, is the simultaneous election practice mentioned above. This practice is based on the assumption that voter behavior will be shaped towards the formation of a parliamentary majority in line with the president and reflects a perspective towards resolving a possible incompatibility between both powers. The second mechanism to prevent the system deadlock includes the budget issue. The previous year's budget can be revised and entry into force in order to avoid a crisis situation caused by the possibility the legislative power does not approve the budget. The third and last mechanism is the principle of mutual renewal of elections. According to this principle, both powers can decide to go for an election, but independent of which force makes this decision, the presidential and parliamentary elections are held together. This situation necessitates the existence of a very serious problem or crisis that cannot be solved by consensus for a possible election decision and strengthens the system functionality (Alkan 2018: 46-48).

In addition to these regulations which are made regarding how the relationship between the legislative and executive powers and each other's should be, various changes have been made in jurisdiction with the new system. In this context, the phrase "neutral" has been added to the constitutional article based on basis of the principle that courts are "independent"; various regulations determining the courts names, the number of members of the courts and selection criteria of those members have been made. However, it should be emphasized that these regulations in jurisdiction are not directly related to the characteristics and functionality of the Presidential System of Government (Akçakaya et. al. 2018: 931). For this reason, it is possible to evaluate these developments as technical regulations consisting of adapting the judiciary functionality with the new system. 
When all regulations made in the scope of the Presidential Government System are contextualized, it can be said that Turkey break with the tradition of parliamentarism ongoing dated from the last quarter of the 19th century, and institutional and managerial principles and practices shaped based on this tradition. As a result of this breaking with the tradition, Turkey has gained a new understanding and a government system named as 'the party-member presidency' or 'Turkish-style presidential system'. Although this aforementioned system can be placed in a framework suitable for the presidential model in terms of its general content, the underlying criteria denoting what the system actually corresponds to and/or what kind of management philosophy it is based on are implicit in the practices period of the passed about 3-years.

\section{IMPLEMENTATION PROCESS OF THE PRESIDENTIAL SYSTEM OF GOVERNMENT}

The execution process of the Presidential Government System in the execution organ started with the "Presidential Decree on Presidential Organization" published in the Official Gazette, Decree No. 1, dated July 10, 2018. With this decree, the institutional structure of the presidential organization and the main actors that will shape public policy have been determined. Thereby, a large number of political and administerial qualified units needed for fulfill the effective implementation of the executive power belonging to the president were established. In this regard, institutional structure consisting of vice presidents, nine policy boards, affiliated institutions and organizations, four offices and sixteen ministries, as well as the administrative affairs department have been established (Official Gazette, dated July 10, 2018:1-192). It is possible to categorize these structures forming the Presidential organization as "staff units" and "supportive units". While the supportive units carry out institutional and administrative affairs, staff units consisting of policy boards and offices emerged as a new organizational model aimed at enhancing the president's public policy formulation capacity (Sobac1 et.al. 2018: 2-3).

After the organizational structure of the presidency, which constitutes the executive power, has been determined, the new system has started to be put into effect and to produce its own practices. The basic instrument that makes these practices come into being is presidential decrees. This instrument, which is new in terms of the Turkish judicial system, has become the primary tool in the implementation of public policies, and has severely limited the possibility of the legislative power to be involved in the process. In fact, this issue causes a series of spreading criticisms that the number of decrees is higher than laws made by the parliament and either neutralize the legislation or steal a role from it. As a matter of fact, it is often criticized that these decrees weaken the legislative role of the parliament, undermined the legal certainty and legal predictability principles, were prepared without negotiation and justification, and changed at short intervals (Gönenç 2019: 3). In the study by Gözler (2019) evaluating the oneand-a-half-year practices of the Presidential Government System in terms of execution, it is stated that the number of decrees issued from July 9, 2018 to December 26, 2019 is 55, however 31 of those were issued for amendments to previous decrees.

Undoubtedly, subjecting the presidential decrees to such intense and harsh criticism arises from the reactions towards the implementation of most of the practices and regulations regarding the execution via this tool. The execution process of the new system started with the Presidential Decree No. 1, continued with the publication of other decrees repeated at short intervals and including pretty detailed regulations. However, these decrees should not be regarded as the only 698 
tool in public policy formulation. Because, in the new system, other tools such as the "presidency annual program" and "100-day action program" which regulate the executive power's activities for operations have been developed. By means of these tools, short and medium term action plans of the executive power have been announced, and the question of what the government does in areas ranging from education to health, from economy to transportation, from defense to foreign policy and the question what it targets for the future have been explained in detail. Within the scope of 2018, when the system came into force, two separate programs containing 100-day execution goals have been published; as to 2019 and 2020, annual programs have been announced for. The first annual program covering the year 2019 was published in the repeated issue of the Official Gazette dated October 27, 2018, and the second annual program covering the year 2020 in the repeated issue of the Official Gazette dated November 4, 2019.

President Recep Tayyip Erdoğan given an inclusive speech on the issues explained in depth in the aforementioned documents at the meeting hold on 21 July 2020, where he evaluated the two-year activities of the Presidential Cabinet (Presidency of The Republic of Turkey, Retrieved from (https://www.tccb.gov.tr/konusmalar/353/120687/cumhurbaskanligi-hukumetkabinesi-iki-yillik-degerlendirme-toplantisi-nda-yaptiklari-konusma), on (22.11.2020)). In this speech, which can be seen as a general performance evaluation of the Presidential Government System, Erdoğan emphasizes that the new system, which provides radical changes in the management structure, presents a dynamic structure that allows for every change needed. Moreover, Erdogan states that they have implemented many structural changes thanks to this system and presidential decrees and says that they will continue with an understanding based on reform, action and change in the next period. Erdogan, who described himself as the person responsible for the executive that the empowered directly by the public and therefore had the right to hold accountability in addition to being legitimate representative of the state as president, states that 64 decrees and 2 thousand 755 decisions were issued during the last two year activities, and that an uninterrupted service was provided to the public in this way, and calls attention to some developments achieved with the new system.

After the adopted to the Presidential Government System, we reduced the number of documents requested from citizens by 95 percent. Processing time of official correspondence decreased on average 71 percent for incoming papers and 32 percent for outgoing papers. We increased the number of institutions in Digital Turkey Platform to 664 with a 44 percent increase, and the number of citizens with e-government passwords increased by 27 percent to 48 million 584 thousand people. In the total number of entries to this platform, we have reached the 1.2 billion level, which was the last year level, in the first 6 months of this year. As a result of all these efforts, our country ranked 22nd among 193 countries in the United Nations e-Government Online Service Index.

Of course, the points that Erdogan pointed out in the second year evaluation meeting are not limited to these issues. After explaining the services in every field from education to health, from justice to security, from energy to agriculture with some data, he concluded the speech by saying that they would continue to march towards Turkey's 2023 goals, as the president and the presidential cabinet.

When Erdogan's speech is evaluated as a whole, it makes an impression on the fact that he is satisfied with the two-year performance and general operation of the system, and again leaves also the door open for possible change demands. However, as stated before, presidential decrees 
constitute the focus of criticism of the system. The central role and importance of the presidential decrees in the context of two years of actions that Erdogan attributes value to, clearly takes to mean that the possible changes will not cover the issues criticized in the context of these decrees. Because the decrees are seen as the main tool of the rapid and effective functioning of the new system and performed as the guarantee of the independence of the executive from the legislative power.

Another unique result of the new system in terms of Turkish political life was the implementation of the party-member presidency. In fact, the history of Turkish Constitutional Law has the past that is familiar with the concept of "party-member president", and the practices which is emerged in this direction. Mustafa Kemal Atatürk, the first president of the Republic of Turkey, held both the presidency and the Republican People's Party (CHP) leadership from 1923 to 1938. İsmet İnönü, who took over the portfolio of the presidency after Atatürk, continued both positions together until 1950. Third President Celal Bayar, resigned from chairperson after the Democratic Party (DP) had come to power and he had been elected as the president. In the following periods, the "objective and supra-party president" model, which was introduced with the 1961 Constitution and preserved in the 1982 Constitution, was adopted and the people elected as the president had to leave their political party memberships and their positions, if any. However, this model did not always work and showed a tendency to the "party-member president" model during the presidency period of leaders having strong political influence and belongings such as Turgut Özal, Süleyman Demirel and Recep Tayyip Erdoğan. These tendencies, which emerged as a result of the interventions by the elected presidents in the political processes in order to maintain their control over their political parties and the government, occasionally caused severe administrative crises and thus instability. The "partymember presidency" model has been included in the constitutional system in order to prevent such objections and to formalize this de facto action that has already taken place (Gönenç 2017: 1-3).

Having won the first elections held in accordance with the new system, Erdoğan had the opportunity to execute the Presidency of the Republic of Turkey and the Chairmanship of the Justice and Development Party (AK Party) together. Although Erdogan's execution of both duties together enabled him to maintain the control over his party and prevent possible crises, it is a fact that this situation also caused problems in the operation of the Presidential Government System. This is because the President, while representing the abstract existence of the state in the person of, he also represents the institutional identity of his party. This makes it difficult to distinguish between the President's works and operations representing the state and its execution-oriented actions, causes questioning of his impartiality and increase in the workload. That is to say, a significant part of the continual criticisms since the first day of the implementation of the new system covers these aforementioned issues arising from the partymember presidency model.

These criticisms and objections to the basic characteristics and practices of the Presidential System of Government have sparked a series of debates about by what name the new system should be called and how it should be defined. The debates shaped around the definition of the Turkish-style presidential system have always been benchmarked within a wide framework that includes the theoretical principles, institutional foundations and implementation practices of the new management model and contemporary/modern world examples. 


\section{RECOGNITION PROBLEM OF THE SYSTEM AND REVISION REQUESTS}

The issue of Turkey's new management model has been the debated subject in the context of how it corresponds to the constitutional law literature and what name it will be called, since the first day of the system. Prominent common emphasis on these ongoing debates about in which government system it will be categorized in and how it will be named is the assessment of that this model has attributes unique to Turkey. Therefore, the name of the new management model, which is accepted by the general public opinion, constitutes an example of uniqueness that will justify this assessment.

However, it should be noted that the unique (sui generis) attributes of the new government model, called the Presidential System of Government, are not limited to its name alone. It is possible to evaluate the basic characteristics and application practices of the model within the same context. The emphasis on the uniqueness of the system, in all the debates that started before the referendum dated April 162017 which constitutes the basis of the implementation of the new model continued until today, comes to the forefront and constitutes the explanation framework for the against to and in favor of the system. In this context there are some opinions such as; as a structure unique to Turkey that have similar practices of other the countries governed by the presidential systems (Sobac1 et.al., 2018: 6), Turkish-style presidential model that emerges as the results of Turkey's internal dynamics and differs from the other presidential systems (İnaç 2018: 333), and as a system adopting the same rules with the presidential system but having differentiated rules to ensure efficient and stable management that Turkey needs (Karatepe et.al., 2017: 36-37).

As can be seen, all the statements about the definition of the new system contain an emphasis on uniqueness. The attributes that makes Turkey's new management model or system unique are explained by referencing to the presidential system. In other words, the Presidential System of Government, is defined as a specific version of a presidential system for Turkey. However, there are also opinion including that the definition which is widely accepted by the public opinion is not true, and although the system unique to Turkey, it is not relation with the presidential system. For example; Gözler (2017: 9-19) stated that Turkey's new government system is 'forces unity government system' rather than the presidential system, and has compared the presidential system in the US with the Turkey's new system in detail with nine item. In the context of this comparison, it is possible to summarize the points as follows:

- While in the United States the President cannot be discharged by legislature, it is possible in Turkey's new system that the President of the Republic can be discharged by making reelection decision.

- While in the United States the President cannot vacate the legislative organ, it is possible in Turkey's new system that the President of the Republic can vacate the parliament by means of making reelection decision.

- While the vice president elected by the people in the United States, in Turkey's system of government the vice president(s) are appointed to by the President.

- While Senate approval is required for the appointment of the ministers in the USA, there is no need for such an approval in Turkey.

- While the appointment of justiciar by the President depends on the Senate approval in United States, such necessity is not in question in Turkey's system. 
- In the US, the authority of the president about appointment of some public officials requires Senate approval, there is no need for this approval in Turkey.

- While international treaties made by the President are subjected to senate approval by a two-thirds vote in US, this rule is beside the point in Turkey.

- While in the USA the president needs to get the budget approved to the Congress; in case if the budget is not approved in Turkey, it is possible that the president can continue by increasing the budget of the previous year.

- While in the USA the relationship between the president and his/her political party is loose, such relationship is liable to be very strict in Turkey.

The results of this elaborative comparison made between the government systems of those two countries, clearly reveal that the new government model in Turkey is not compatible with the classical meaning and operation of presidential system in constitutional law literature. Likewise, as stated above that the system in Turkey has emerged as a result of the specific conditions and has been become clear as "concretized a party-member presidency as a presidential system" (İnaç 2018: 337). The emphasis on clarification here reveals that the structuring process regarding the new management model continues. On one side of this structuring process, there are commendatory views recommending the revision of the new system in some respects, and on the other side, there are dissenter opinion defending a return to the classical parliamentary system. Especially the Nation Alliance, including the main opposition party CHP, almost all the opposition parties demand the abandonment of the Presidential Government System and switching to a strengthened parliamentary system. On the contrary, The People's Alliance consisting of the AK Party and the Nationalist Movement Party (MHP) have focused more on the revision of the system. As a matter of fact, President Erdoğan (July 21, 2020), in his speech mentioned above, stated that with the new management model, "a dynamic system that allows any change to be made quickly when necessary and when needed" is being built, and said that the doors are always open to quests and demands to find the better. Making changes in practices of party-member presidency, the re-establishment of the undersecretariat, which is the cornerstone of the state bureaucracy, increasing the number of ministries and strengthening relations between legislature and the presidential cabinet are the leading issues demanding revisions regarding the new system (Retrieved from (Aydınlık, 30 October 2020, https://www.aydinlik.com.tr/haber/cumhurbaskanligi-hukumet-sisteminderevizyon-hazirligi-222119), on (23.11.2020)). These demands on Turkey's new government system are increasingly mentioned, and the expectations to the system revision are growing in each passing day. Undoubtedly, in addition to the criticism and objections of the opposition parties, the deficiencies arising from the construction of the system and the disruptions experienced in the implementation process have a great effect on this growth.

\section{CONCLUSION}

Turkey adopted a new management model which is also called the Presidential System of Government by referendum held on April 16, 2017. This adopted model have come into force after the elections held on June 24, 2018, and Recep Tayyip Erdoğan became the first president of the Presidential Government System. Eventually, Turkey has moved away from the parliamentary system which is shaped in the developmental stages of Turkish-Ottoman modernization and has approximately 150-years history, and entered new era.

The implementation process of the new period and consequently the new system, which started under Erdoğan's leadership and is approaching its third year, has basically been shaped around 702 
three issues. The first issue is the Presidential Decree No. 1, which constitutes the institutional structure of the executive power and therefore the organizational framework of the new management model. With this decree, the supportive and staff units of the presidency that constitute the executive power were determined and an institutional architecture unique to the new system was created. The second issue that shapes the implementation process of the new system is the presidential decrees that also provides the implementation of the first issue. It is possible to say that these decrees serving as the primary means of reflecting the decisions and policies of the executive power into practice represent the founding role and power of the president in the system. The regulation, that allows taking the lead in the process as the partymember president within the context of the possibilities provided by the Presidential Government System, constitutes the third and the last issue.

All these issues come together in an institutional process concentrated on the person of the president, and shape the implementation process of the new management model, also known as the Turkish-style presidential system, or in other words, the Presidential Government System. As of today, the Presidential Government System, which has left two years behind and is approaching its third year, has been and continues to be at the center of intensive debates since the referendum process. It is observed that these debates, which take place around the theoretical framework and institutional functioning of the new government system and the implementation practices, have two different sides. While the first side is composed of opposition parties, groups and individuals who demands the complete abandonment of the new system, which it claims to have bypassed the legislative power and created a one-man regime, and advocates a return to the strengthened parliamentary system; the second side consists of pro-government or in favor of the government blocks that wants the new system to be revised from certain angles and to have a healthier functioning. However, it is observed that both proposition and opposition sides of the debates on the new system agree on some issues. Although the reasons and the tones of emphasis are different, the criticisms and objections that the founding role and power provided to the executive are inactivating or at least weakening the legislature and its members are the main issues that both sides have in common. It is seen that there is also a similar common view regarding the problems in the general functioning and performance of the system caused by the part-member presidential model.

\section{REFERENCES}

AKÇAKAYA, M. \& ÖZDEMİR, A. (2018). “Cumhurbaşkanlığı Hükümet Sistemi ve Siyasal İstikrar”, Üçüncü Sektör Sosyal Ekonomi, 53 (3): 922-944.

ALKAN, H. (2018). “Cumhurbaşkanlığg Sisteminin Kurumsal Özellikleri ve Demokratikleşme Sürecine Olası Etkileri”, Türkiye İletişim Araştırmaları Dergisi, 2018 Özel Sayı: 139153.

Aydınlık, "Cumhurbaşkanlığı Hükümet Sisteminde Revizyon Hazırlı̆̆ı", https://www.aydinlik.com.tr/haber/cumhurbaskanligi-hukumet-sisteminde-revizyonhazirligi-222119 (Accessed 23 November 2020).

DEMİRKAYA, Y. (2018). “Cumhurbaşkanlığı Hükümet Sistemi ve Kamu Yönetimi’nde Yeni Aktörler: Sivil Toplum Örgütleri”, Cumhurbaşkanlığı Hükümet Sistemi: Kamu Yönetiminde Değişim, Editör: Yüksel Demirkaya, İstanbul: Hiperyayın: 13-34.

GÖNENÇ, L. (2017). "Partili Cumhurbaşkanı”, TEPAV Politika Notu: 1-4. 
GÖNENÇ, L. (2019). "Hükümet Sistemi Tartışmaları-2: Cumhurbaşkanlığı Hükümet Sistemi’nin Bir Y1llık Performansı", TEPAV Politika Notu, 1-3.

GÖZLER, K. (2017). "Cumhurbaşkanlığı Sistemi mi, Başkanlık Sistemi mi, Yoksa Neverland Sistemi mi? 16 Nisan'da Neyi Oylayacağı??”, http://www.anayasa.gen.tr/neverland.pdf (Accessed 24 February 2017).

GÖZLER, K. (2019). “Cumhurbaşkanlığı Hükûmet Sisteminin Uygulamadaki Değeri: Bir Buçuk Yıllık Bir Bilanço”, www.anayasa.gen.tr/cbhs-bilanco.htm (Accessed 21 November 2020).

İNAÇ, H. (2018). “Türk Tipi Başkanlık Sistemi”, Cumhurbaşkanlığı Hükümet Sistemi: Kamu Yönetiminde Değişim, Editör: Yüksel Demirkaya, İstanbul: Hiperyayın: 329-346.

KARATEPE, Ş., ALKAN, H., ATAR, Y., BINGÖL, Y., \& DURGUN, G. B. (2017). Sorularla Cumhurbaşkanlığı Hükümet Sistemi. Memur-Sen Yayınları, Ankara.

Official Gazette, Number: 30474, 10 July 2018.

Official Gazette, Number: 30578 (Mükerrer), 27 October 2018.

Official Gazette, Number: 30938 (Mükerrer), 4 November 2019.

SOBACI, M. Z., MIŞ, N., \& KÖSEOĞLU, Ö. (2018). “Türkiye'nin yeni yönetim modeli ve Cumhurbaşkanlığı teşkilatı”, Seta Perspektif, 206, 1-6.

TEKİN, Y. (2015). Başkanlık Sistemi ve Kuvvetler Ayrılığı Tartışmaları, İstanbul: Kesit Yay.

TURAN, A. M. (2018). “Türkiye’nin Yeni Yönetim Düzeni: Cumhurbaşkanlığı Hükümet Sistemi”, Social Sciences Research Journal, 7 (3): 42-91.

Türkiye Cumhuriyeti Cumhurbaşkanlığı, "Cumhurbaşkanlığı Hükümet Kabinesi İki Yıllık Değerlendirme Toplantısı'nda Konuşma”, https://www.tccb.gov.tr/konusmalar/353/120687/cumhurbaskanligi-hukumet-kabinesiiki-yillik-degerlendirme-toplantisi-nda-yaptiklari-konusma (Accessed 22 November 2020).

YILDIZ, A. (2015). “Giriş”, Karşılaştırmalı Hükümet Sistemleri: Başkanlık Sistemi, Editör: Havvana Yapıcı Kaya, Ankara: TBMM Araştırma Merkezi Yay. (2), 136-147. 